\title{
Tingkat penerimaan penggunaan jamu sebagai alternatif penggunaan obat modern pada masyarakat ekonomi rendah-menengah dan atas
}

\author{
Society's acceptance level of herb as alternative to modern medicine for \\ lower, middle, and upper class group
}

\author{
Andriati $^{1}$ dan $\underline{\text { R.M. Teguh Wahjudi }}{ }^{2}$ \\ 1) Ilmu Farmasi Kedokteran dan Rehabilitasi, Fakultas Kedokteran, Universitas \\ Airlangga \\ 2) Ilmu Farmasi Kedokteran, Fakultas Kedokteran, Universitas Airlangga \\ Korespondensi: Fakultas Kedokteran, Universitas Airlangga, Jalan Prof. Dr. Moestopo, \\ Surabaya, Indonesia \\ E-mail: rmteguh.wahjudi@gmail.com
}

\begin{abstract}
Herbs have become an important cultural heritage from Indonesia, as the consumption of herbs increased into $50 \%$. This research is particularly important to analyze health quality of society through herbs as alternative of modern medicine to lower, middle, upper-social class group. The research problem addressed is how is the acceptance level of herb as alternative of modern medicine to middle, lower and upper class society in East Java. After finding the acceptance level of lower, middle, and upper class group toward herb usage, further analysis was focused on herbs management model in order to enhance society's health quality. Analysis unit in this research are society and bureaucracy. Informant was chosen by purposive sampling method (for key informants) and snowball method for complementary informant. Data was analyzed using qualitative technique. The research shows that the use of herbs as alternative of modern medicine in lower-middle class group was relatively high (58\%). The local government have a strategic role in managing herbs through policy innovation for health service in the local community. There is also an urgency to conduct a guidance, research, tax reduction, a more sophisticated method of herbal plant cultivation, herbs standardization, and strict supervision for herbs usage.
\end{abstract}

Keywords: herbs acceptance, modern medicine alternative, tradition, health-seeking behavior

\begin{abstract}
Abstrak
Jamu telah menjadi bagian budaya dan kekayaan alam Indonesia. Penggunaan jamu oleh masyarakat Indonesia mencapai jumlah lebih dari 50\%. Penelitian ini penting untuk mengetahui kualitas kesehatan masyarakat melalui penggunaan jamu sebagai alternatif penggunaan obat modern pada masyarakat ekonomi rendah-menengah dan atas. Permasalahan yang ingin dijawab dalam penelitian ini adalah bagaimana tingkat penerimaan penggunaan jamu sebagai alternatif penggunaan obat modern pada masyarakat ekonomi rendah-menengah dan atas di Jawa Timur. Langkah lebih lanjut setelah diketahui tingkat penerimaan penggunaan jamu sebagai alternatif penggunaan obat modern pada masyarakat ekonomi rendah-menengah dan atas di Jawa Timur adalah model pengelolaan untuk meningkatkan kualitas kesehatan masyarakat. Penelitian ini menggunakan pendekatan penelitian kualitatif. Unit analisis penelitian adalah masyarakat dan birokrasi. Penentuan informan secara purposif sampling (untuk informan kunci) dan snow ball untuk pengembangan informan. Teknik analisis data menggunakan metode analisis data kualitatif mengikuti. Hasil penelitian penerimaan penggunaan jamu sebagai alternatif penggunaan obat modern pada masyarakat ekonomi rendah-menegah dan atas secara umum tinggi (58\%). Pemerintah lokal melalui program onotomi daerah memiliki peran strategis dalam pengelolaan jamu (pelayanan kesehatan) melalui inovasi kebijakan pelayanan kesehatan yang diterapkan pada pemerintah lokal. Model pengelolaan jamu untuk meningkatkan kualitas pelayanan kesehatan masyarakat perlu ada pendampingan, riset, pengurangan pajak, pengembangan tanaman obat, sosialisasi hasil riset, standarisasi jamu, dan pengawasan pengguna jamu secara ketat.
\end{abstract}

Kata kunci: penerimaan jamu, alternatif pengobatan modern, tradisi, perilaku berobat 


\section{Pendahuluan}

Jamu telah menjadi bagian budaya dan kekayaan alam Indonesia dan hasil Riset Kesehatan Dasar menunjukkan bahwa penggunaan jamu oleh masyarakat Indonesia lebih dari 50\%. Jamu merupakan bagian dari pengobatan tradisional. Pengobatan tradisional telah berkembang secara luas di banyak negara dan semakin populer. Indonesia memiliki kekayaan tanaman obat dan ramuan jamu dari berbagai suku yang tersebar di berbagai wilayah indonesia mulai Sabang sampai Merauke. Jamu adalah warisan leluhur bangsa yang telah dimanfaatkan secara turun temurun untuk pengobatan dan pemeliharaan kesehatan. Riset menunjukkan bahwa 49,53\% penduduk Indonesia menggunakan jamu baik untuk menjaga kesehatan maupun untuk pengobatan karena sakit. Penduduk yang mengkonsumsi jamu sebanyak 95,6\% menyatakan merasakan manfaat minum jamu. Hasil Riskesdas tahun 2010 juga menunjukkan bahwa dari masyarakat yang mengkonsumsi jamu, 55,3\% mengkomsumsi jamu dalam bentuk cairan (infusum/decoct), sementara sisanya (44,7\%) mengkonsumsi jamu dalam bentuk serbuk, rajangan, dan pil/kapsul/tablet (Badan Litbang Kesehatan 2010).

Meskipun demikian belum semua dokter di Indonesia menerima pengobatan jamu dengan alasan tidak memiliki bukti ilmiah (evidence based medicine/EBM). Hal tersebut diperjelas dengan hilangnya bidang kajian pengobatan tradisional, alternatif dan komplementer pada kepengurusan Ikatan Dokter Indonesia (PB IDI) pasca-Muktamar IDI di Makasar tahun 2012. Bidang kajian tersebut diperjuangkan PB IDI hasil muktamar di Palembang tahun 2009, setelah Bapak Presiden RI mencanangkan jamu brand Indonesia pada tahun 2008. Pada kenyataannya, di setiap sidang pleno PB IDI selama tiga tahun, banyak anggota pengurus yang selalu mempertanyakan bukti ilmiah jamu karena banyak pasien mereka mengalami perforasi lambung bahkan gagal ginjal. Penjelasan bahwa jamu tersebut bercampur dengan bahan kimia obat (BKO) sebagai penyebab efek samping, tidak menyurutkan pendapat mereka bahwa jamu tidak aman dan tidak berbasis ilmiah (Purwaningsih 2013). Pendapat dokter yang melemahkan kemanfaatan jamu tersebut mendorong, Kementerian Kesehatan melalui Badan Penelitian dan Pengembangan Kesehatan menjalankan program saintifikasi jamu (SJ) berdasarkan Peraturan Kementerian Kesehatan RI No.003/PerMenKes/I/2010 untuk membuktikan khasiat jamu dengan metode penelitian berbasis pelayanan. Masalah di atas merupakan sebagian kecil dari masalah yang kompleks karena peningkatan jamu bukan hanya masalah kementerian kesehatan saja, melainkan melibatkan berbagai kementerian yang terkait pengelolaan jamu dari hulu ke hilir misalnya kementerian pertanian, kehutanan, riset dan teknologi, pendidikan dan kebudayaan, perindustrian, perdagangan dan lain-lain.

Permasalahan dalam penelitian ini adalah bagaimana tingkat penerimaan penggunaan jamu sebagai alternatif penggunaan obat modern pada masyarakat ekonomi rendah-menengah dan atas di Jawa Timur. Langkah lebih lanjut setelah diketahui tingkat penerimaan penggunaan jamu sebagai alternatif penggunaan obat modern pada masyarakat ekonomi rendah-menengah dan atas di Jawa Timur adalah model pengelolaan untuk meningkatkan kualitas kesehatan masyarakat. Berdasarkan latar belakang di atas dirumuskan permasalahan penelitian sebagai berikut (1) Bagaimana penerimaan penggunaan jamu sebagai alternatif penggunaan obat modern pada masyarakat ekonomi rendah-menengah dan atas? (2) Bagaimana peran strategis dinas kesehatan dalam kebijakan jamu pada pemerintah lokal? (3) Bagaimana model pengelolaan jamu untuk meningkatkan kualitas kesehatan masyarakat?

Keberadaan jamu tidak bisa dilepaskan dengan sejarah peradaban di Indonesia. Hal ini dapat diketahui sebelum Abad ke 18, dengan ditemukannya fosil di tanah Jawa berupa lumpang, alu dan pipisan yang terbuat dari batu menunjukkan, bahwa penggunaan ramuan untuk kesehatan telah dimulai sejak zaman mesoneolitikum. Penggunaan ramuan untuk pengobatan tercantum di prasasti sejak abad $5 \mathrm{M}$ antara lain relief di Candi Borobudur, Candi Prambanan dan Candi Penataran abad 8-9 M. Usada Bali merupakan uraian penggunaan jamu yang ditulis dalam bahasa Jawa Kuno, Sansekerta dan Bahasa Bali di daun lontar pada tahun 991-1016 M. Istilah djamoe dimulai sejak abad 15-16 M yang tersurat dalam primbon di Kartasuro. Uraian jamu secara lengkap terdapat di Serat Centini yang ditulis oleh Kanjeng Gusti Adipati Anom Mangkunegoro III tahun 1810-1823. Pada tahun 1850 R. Atmasupana II menulis sekitar 1734 ramuan jamu. Djamoe merupakan singkatan dari djampi yang 
berarti doa atau obat dan oesodo (husada) yang berarti kesehatan. Dengan kata lain djamoe berarti doa atau obat untuk meningkatkan kesehatan (Pringgoutomo 2007, Tilaar 2010).

Pemanfaatan jamu di berbagai daerah dan/atau suku bangsa di Indonesia, selain Jawa, belum tercatat dengan baik. Menurut Pols (2010) sejak zaman penjajahan Belanda pada awal abad ke-17, para dokter berkebangsaan Belanda, Inggris ataupun Jerman tertarik mempelajari jamu sampai beberapa di antaranya menuliskannya ke dalam buku, misalnya "Practical Observations on a Number of Javanese Medications" oleh dr. Carl Waitz pada tahun 1829. Isi buku antara lain menjelaskan bahwa obat yang lazim digunakan di Eropa dapat digantikan oleh herbal/tanaman (jamu) Indonesia, misalnya rebusan sirih (Piper bettle) untuk batuk, rebusan kulit kayu manis (Cinnamomum) untuk demam persisten, sedangkan daunnya digunakan untuk gangguan pencernaan. The Weltevreden Military Hospital pada tahun 1850, seorang ahli kesehatan Geerlof Wassink membuat kebun tanaman obat dan menginstruksikan kepada para dokter agar menggunakan herbal untuk pengobatan. Hasil pengobatan tersebut dipublikasikan di Medical Journal of the Dutch East Indies. Seorang ahli farmasi, Willem Gerbrand Boorsma yang saat itu bertugas sebagai direktur "Kebun Raya Bogor" pada tahun 1892 berhasil mengisolasi bahan aktif tanaman dan membuktikan efeknya secara farmakologis yaitu morfin, kinin dan koka. Pada abad ke-19 diterbitkan buku tentang pemanfaatan jamu di Indonesia oleh dr. Cornelis L. van der Burg yaitu Materia indica. Penemuan teori baru tentang bakteri oleh Pasteur dan ditemukannya sinar X pemanfaatan jamu menurun drastis pada awal tahun 1900. Pada akhir tahun 1930, dr. Abdul Rasyid dan dr. Seno Sastroamijoyo menganjurkan penggunaan jamu sebagai upaya preventif untuk menggantikan obat yang sangat mahal. Pada tahun 1939, IDI mengadakan konferensi dan mengundang dua orang pengobat tradisional untuk mempraktikkan pengobatan tradisional di depan anggota IDI. Mereka tertarik untuk mempelajari seni pengobatan tradisional Indonesia dan pada tahun yang sama, di Solo diadakan konferensi I tentang jamu yang dihadiri juga oleh para dokter (Webster 2008).

Penggunaan jamu meningkat tajam saat penjajahan Jepang. Pada kurun waktu tersebut, terdapat tiga pabrik jamu besar yaitu PT Jamoe Iboe Jaya (1910), PT Nyonya Meneer (1919) dan PT Sido Muncul (1940). Pada tahun 1966, diadakan konferensi II tentang jamu, juga di Solo untuk mengangkat kembali penggunaan jamu setelah hampir 20 tahun terlupakan terutama akibat perang dunia II yang berdampak pada sosial-ekonomi masyarakat Indonesia terutama di Jawa (Webster 2008). Sejak saat itu, banyak pabrik jamu bermunculan terutama di Jawa Tengah. Banyaknya pendirian industri jamu, pemerintah melindungi konsumen dengan mengeluarkan Peraturan Menteri Kesehatan No. 246/MENKES/PER/V/1990 tentang Izin Usaha Industri Obat Tradisional dan Pendaftaran Obat Tradisonal. Guna menjamin peningkatan penggunaan dan pengawasan terhadap obat tradisional, pemerintah mengeluarkan Keputusan Menteri Kesehatan No. 584/MENKES/SK/VI/1995 tentang Sentra Pengembangan dan Penerapan Pengobatan Tradisional (SP3T).

Pada abad ke-21, para pakar jamu baik peneliti di institusi pendidikan, lembaga pemerintah maupun industri jamu terus berjuang agar jamu menjadi tuan rumah di negeri sendiri. Berbagai seminar tentang jamu dan/atau obat tradisional Indonesia mulai meningkat. Masing-masing kementerian berlomba-lomba menyusun peta jalan (road map) tentang jamu/obat tradisional Indonesia. Siapa sebenarnya yang menjadi koordinator penyusunan peta jalan tersebut juga tidak jelas, sampai akhirnya disepakati akan dikoordinasi oleh Kementerian Koordinator Ekonomi dan Industri yang akan menyiapkan peristiwa nasional Hari Kebangkitan Jamu dan Jamu dijadikan brand Indonesia pada tahun 2007. Selanjutnya, dikeluarkan keputusan Menteri Kesehatan No. 381/MENKES/SK/III/2007 tentang Kebijakan Obat Tradisional dan Peraturan Menteri Kesehatan No.1109/ MENKES/PER/IX/2007 tentang Penyelenggaraan Pengobatan Komplementer-Alternatif di fasilitas pelayanan kesehatan (Purwaningsih 2013).

Pada tanggal 27 Mei 2008, Hari Kebangkitan Jamu Indonesia diresmikan Presiden Indonesia Bapak Susilo Bambang Yudoyono, di Istana Merdeka sekaligus meresmikan jamu sebagai brand Indonesia. Jamu seakan mewarnai kembali kebijakan pemerintah setelah pencanangan tersebut yaitu dalam bentuk Undang-Undang No. 36 tahun 2009 tentang kesehatan. Pada pasal 48 ayat 1 disebutkan bahwa dari 17 upaya kesehatan tercantum upaya pelayanan kesehatan tradisional yaitu pengobatan dan/atau 
perawatan dengan cara dan obat yang mengacu pada pengalaman dan keterampilan turun temurun secara empiris yang dapat dipertanggungjawabkan dan diterapkan sesuai dengan norma yang berlaku di masyarakat. Pada saat bersamaan, kementerian kesehatan menyusun Standar Pelayanan Medik Herbal yang tertuang dalam Keputusan Menteri Kesehatan No. 121/MENKES/SK/II/2008 diikuti dengan Keputusan Menteri Kesehatan RI No. 261/Menkes/SK/IV/2009 tentang Farmakope Herbal Indonesia Edisi pertama.

Pada tahun 2007, Kepala Badan Penelitian dan Pengembangan Kesehatan Kementerian Kesehatan RI memprakarsai isian kuesioner riskesdas 2007 tentang pemanfaatan jamu oleh masyarakat Indonesia. Hasilnya menunjukkan bahwa 35,7\% masyarakat menggunakan jamu dan lebih dari $85 \%$ di antaranya mengakui bahwa jamu bermanfaat bagi kesehatan (Kemenkes 2010). Riskesdas 2010 ternyata menunjukkan peningkatan hasil yaitu 59,12\% dari 35,7\% dan 95,6\% dari 85\% (Kemenkes 2010). Selain pencapaian hasil yang bermakna dalam riskesdas 2007 dan 2010, disiapkan pula program saintifikasi Jamu untuk membuktikan secara ilmiah bahwa jamu efektif untuk indikasi tertentu dengan metode penelitian berbasis pelayanan.

Penggunaan jamu sebagai alternatif pengobatan di samping obat modern pada masyarakat merupakan bagian dari indigenous knowledge masyarakat. Pemakaian jamu dan obat tradisional lainnya yang dilakukan secara turun temurun tidak terlepas dari peran orang tua dalam melestarikan budaya. Penelitian yang dilakukan oleh Siti Partini (1999) mengenai perilaku berobat pada lansia, antara lain menyimpulkan bahwa salah satu cara menjaga kesehatan yang dilakukan masyarakat Daerah Istimewa Yogyakarta (terutama wanita) adalah dengan sering mengkonsumsi ramuan jamu Jawa yang harganya relatif murah. Hasil penelitian (Partini 1999) mengenai pola hidup lansia di Daerah Istimewa Yogyakarta menemukan bahwa para lanjut usia di DIY menjaga kesehatan tubuhnya dengan minum jamu dan berolah raga, sedangkan untuk kesehatan mental/psikologis dengan hidup sumeleh (menyerahkan diri kepada Tuhan Yang Maha Esa).

Hasil-hasil penelitian tersebut lebih menekankan penggunaan jamu Jawa pada masyarakat umum, lansia, dan wanita. Sebetulnya, jamu dapat digunakan juga untuk anak-anak. Menurut Geertz (1961) obat tradisional bukan semata-mata hanya untuk wanita namun tersedia pula untuk laki-laki dan anakanak. Jamu memiliki beberapa keunggulan, seperti toksisitasnya rendah dan efek samping yang ditimbulkan ringan. Berdasarkan pemikiran ini peneliti ingin mengetahui penerimaan penggunaan jamu sebagai alternatif penggunaan obat modern pada masyarakat ekonomi rendah-menengah dan atas; peran strategis dinas kesehatan dalam kebijakan jamu pada pemerintah lokal; model pengelolaan jamu untuk meningkatkan kualitas kesehatan masyarakat.

Tingkat penggunaan jamu sebagai alternatif penggunaan obat modern pada masyarakat ekonomi rendah-menengah dan atas memang dipengaruhi banyak aspek. Faktor-faktor yang mempengaruhi konsumen membeli jamu meliputi faktor pribadi, faktor bauran pemasaran dan faktor sosial, budaya dan psikologi (Mulyani 2007). Aspek budaya memegang peran penting dalam mengkonsumsi jamu. Hal yang menarik peneliti adalah apakah pada era globalisasi, modernisasi serta metode pengobatan modern yang canggih didukung oleh peralatan yang maju, faktor-faktor pribadi, faktor bauran pemasaran dan faktor sosial, budaya dan psikologi masih menjadi pertimbangan dalam mengkonsumsi jamu pada masyarakat.

\section{Metode Penelitian}

Penelitian ini menggunakan pendekatan penelitian kualitatif. Penelitian kualitatif adalah tepat digunakan dalam penelitian penerimaan penggunaan jamu sebagai alternatif penggunaan obat modern pada masyarakat ekonomi rendah-menengah dan atas karena pertama peneliti melakukan penelitian pada latar belakang alamiah atau objek secara keseluruhan (entity), sehingga menggambarkan objek sesuai dengan kondisi sewajarnya (natural setting). Sementara, bagi Bogdan dan Taylor (1975), penelitian kualitatif adalah proses penelitian yang menghasilkan data deskriptif berupa data tertulis/lisan dari subjek dan objek yang diamati/diteliti. Penelitian dilakukan di Surabaya, Bangkalan 
Madura dan Magetan. Pemilihan lokasi ini didasarkan pada beberapa argumentasi (a) kota Surabaya merupakan pusat perdagangan termasuk jamu sebelum didistribusi pada masyarakat Jawa Timur; (b) pengguna jamu erat dengan kultur masyarakat. Berkaitan dengan keterkaitan ini peneliti ingin mengetahui tingkat penggunaan jamu pada maasyarakat Kultur Mataraman (Magetan) dan Kultur Madura (Bangkalan); dan (c) berdasarkan data nilai HDI (human development index) capaian Kota Surabaya, Bangkalan dan Magetan.

Unit analisis penelitian adalah masyarakat, khususnya masyarakat pengonsumsi jamu pada Kota Surabaya, Bangkalan dan Magetan. Hal ini berkaitan dengan Permasalahan penelitian yang diajukan di atas. Penelitian ini adalah penelitian kualitatif deskriptif. Pengertian penelitian kualitatif dapat diartikan sebagai penelitian yang menghasilkan data deskriptif mengenai kata-kata lisan maupun tertulis. Penelitian deskriptif dipilih peneliti untuk menjawab pertanyaan mengenai the what, who, why, where, when, dan how-nya obyek penelitian. Agar pengumpulan data dan informasi berjalan efektif dan efisien dilakukan dengan tiga tahapan yaitu wawancara mendalam, observasi dan dokumentasi. Pelaksanaan pengumpulan data di lapangan diatur melalui strategi sebagai berikut, (a) penentuan informan secara purposif sampling (untuk informan kunci) dan snow ball untuk pengembangan informan, (b) mewawancarai informan, (c) membuat catatan, (d) mengajukan pertanyaan deskriptif dan struktural, 5) melakukan analisis wawancara, (e) membuat analisis domain, (f) menemukan tema-tema berkaitan dengan penerimaan penggunaan jamu sebagai alternatif penggunaan obat modern pada masyarakat ekonomi rendah-menengah dan atas selanjutnya dapat dirumuskan model pengelolaan jamu untuk meningkatkan kualitas kesehatan masyarakat, dan (g) menuliskan laporan penelitian. Pengumpulkan data dilakukan dengan kuesioner. Langkah ini dimaksudkan agar diperoleh gambaran data penelitian konsumsi jamu oleh masyarakat. Hakikatnya data dari kuesioner adalah data pendukung data wawancara. Peneliti telah menyebarkan 160 kuesioner pada masyarakat di Surabaya, Madura dan Magetan secara acak (random).

Pemeriksaaan keabsahan data pada penelitian ini digunakan teknik triangulasi sumber data, dilakukan dengan: (a) membandingkan data hasil pengamatan dan hasil wawancara, (b) membandingkan apa yang dikatakan orang di depan umum dengan apa yang dikatakan secara pribadi, (c) membandingkan keadaan dalam perspektif seseorang dengan pendapat dan pandangan orang lain, (d) membandingkan hasil wawancara dengan isi dokumen. Penelitian ini menggunakan teknik analisis data kualitatif mengikuti Miles dan Huberman (1992). Analisis ini terdiri dari tiga alur yaitu: (a) reduksi data, yang diartikan sebagai proses pemilihan, pemusatan perhatian pada penyederhanaan, pengabstrakan dan transformasi data kasar yang muncul dari catatan-catatan tertulis di lapangan, (b) Penyajian data dilakukan dengan menggunakan bentuk teks naratif, dan (c) penarikan simpulan. Data yang diperoleh dilakukan pemaparan serta interpretasi secara mendalam.

\section{Penerimaan penggunaan jamu sebagai alternatif penggunaan obat modern pada masyarakat ekonomi rendah-menengah dan atas}

Integrasi pelayanan kesehatan tradisional dalam pelayanan kesehatan formal merupakan suatu program pemerintah utamanya Kementerian Kesehatan, melalui Bina Kestradkom sebagai leading pelayanan dan Badan Litbangkes sebagai leading penemuan evidence base, disertai dukungan seluruh unit kerja terkait di Kementerian Kesehatan dan unit kerja lain di Indonesia. Dalam 5 tahun terakhir berkembang pesat mengenai penggunaan jamu di masyarakat, baik masyarakat sebagai pengguna maupun masyarakat profesi tenaga kesehatan sebagai pemberi jasa pelayanan. Dari kalangan profesi tenaga kesehatan, perhatian terhadap obat tradisional mulai dirasakan, dengan berdirinya berbagai perhimpunan tenaga dokter seminat, misalnya PDHMI, PKKAI, PERDESTI dll, yang intinya menggunakan tanaman obat/obat tradisional sebagai modalitas terapi. Pada tahun 2010 terjadi suatu terobosan dengan diterbitkannya Permenkes 003/PERMEN///2010 mengenai Saintifikasi Jamu dalam penelitan berbasis pelayanan. Di tahun yang sama, dilakukan pemetaan dokter praktik jamu se Jawa Bali, dan didapatkan 159 dokter dari profesi peminat, dan sebanyak 76,9\% melakukan praktik dengan obat tradisional atau jamu, sebagai alternatif maupun sebagai komplementer. 
Faktor-faktor yang mempengaruhi konsumen membeli jamu meliputi faktor pribadi, faktor bauran pemasaran dan faktor sosial, budaya dan psikologi (Mulyani 2007). Faktor pribadi adalah faktor utama dalam mengkonsumsi jamu karen hal ini didasari keinginan pribadi dari individu yang bersangkutan untuk mengkonsumsi jamu. Faktor pemasaran merupakan implikasi dari iklan yang dibuat oleh perusahaan atau pabrik pembuat jamu. Faktor sosial adalah konsumsi jamu yang dilakukan individu karena saran orang-orang yang ada di sekitarnya (keluarga-sahabat-teman-kolega dll). Aspek budaya merupakan aspek kultural masyarakat di Nusantara yang telah mengkonsumsi jamu sebagai upaya menjaga kesehatan tubuh dan menyembuhkan penyakit. Faktor psikologi adalah konsumsi jamu yang dilakukan individu karena mengalami jalan buntu (tidak sembuh) pada saat mengkonsumsi obat farmasi (obat modern) sehingga beralih atau mengkonsumsi jamu bersama obat modern. Di antara faktor yang telah disebutkan di atas, aspek budaya memegang peran penting dalam mengkonsumsi jamu.

Penggunaan jamu sebagai alternatif penggunaan obat modern dapat diketahui dari seberapa besar konsumsi jamu oleh masyarakat. Berdasarkan data penggunaan jamu sebagai alternatif penggunaan obat modern pada masyarakat ekonomi rendah-menengah dan atas seperti pada Tabel 1.

Tabel 1.

Tingkat konsumsi jamu masyarakat ekonomi rendah-menengah dan atas

\begin{tabular}{llll}
\hline Tingkat ekonomi & Pendapatan & Jumlah & Persen \\
\hline Rendah & $<1 \mathrm{jt} /$ bulan & 93 & $58 \%$ \\
Menegah & $1,5-5$ jt/bulan & 40 & $25 \%$ \\
Atas & $>5 \mathrm{jt} / \mathrm{bulan}$ & 27 & $17 \%$ \\
\hline
\end{tabular}

Sumber data: primer penelitian

Berdasarkan data di atas sebagian besar masyarakat masih mengkonsumsi jamu (58\%). Hal ini dapat diinterpretasi jamu masih menjadi alternatif penyembuhan penyakit atau menjaga kesehatan di samping obat modern. Berkaitan dengan tingkat penerimaan jamu oleh masyarakat diperoleh data seperti pada Tabel 2 .

Tabel 2.

Tingkat penerimaan jamu oleh masyarakat

\begin{tabular}{llc}
\hline Saya puas dengan produk jamu & Tidak setuju dan Sangat tidak setuju & $7 \%$ \\
yang saya minum & Ragu-ragu & $33 \%$ \\
& Setuju dan Sangat Setuju & $60 \%$ \\
Saya benar-benar menyukai produk & Tidak setuju dan Sangat tidak setuju & $6 \%$ \\
jamu & Ragu-ragu & $36 \%$ \\
& Setuju dan Sangat Setuju & $58 \%$ \\
Saya menganjurkan kepada orang & Tidak setuju dan Sangat tidak setuju & $9 \%$ \\
lain untuk minum jamu & Ragu-ragu & $23 \%$ \\
& Setuju dan Sangat Setuju & $68 \%$ \\
Saya selalu minum jamu & Tidak setuju dan Sangat tidak setuju & $19 \%$ \\
& Ragu-ragu & $22 \%$ \\
Saya mengutamakan minum jamu & Setuju dan Sangat Setuju & $59 \%$ \\
dibanding obat farmasi (dokter) & Tidak setuju dan Sangat tidak setuju & $5 \%$ \\
& Ragu-ragu & $49 \%$ \\
Saya mengutamakan minum jamu & Setuju dan Sangat Setuju & $46 \%$ \\
dibanding obat jamu buatan luar, & Tidak setuju dan Sangat tidak setuju & $21 \%$ \\
seperti China, Korea dll & Ragu-ragu & $15 \%$ \\
\hline
\end{tabular}

Sumber data: primer penelitian

Berdasarkan Tabel 2 diketahui bahwa kecenderungan masyarakat merasa puas dengan produk jamu yang dikonsumsi yaitu (60\%) dan menyukai produk jamu (58\%). Pada kalangan masyarakat terjadi 
penyebarluasan informasi jamu melalui jaringan sosial kepada orang lain untuk minum jamu (68\%), yang terjadi sebagian masyarakat mengutamakan mengkonsumsi jamu (46\%) dan lebih mempercayai jamu buatan dalam negeri (64\%) karena harganya lebih terjangkau dan mudah diperoleh.

\section{Faktor pribadi mengkonsumsi jamu}

Konsumsi jamu merupakan bagian pilihan dalam hidup manusia. Peneliti katakan demikian karena, individu dalam konsumsi jamu merupakan sebuah pilihan. Artinya individu dapat memilih beberapa alternatif lain dalam upaya menjaga kesehatan dan menyembuhkan penyakit yaitu dengan obat farmasi. Produk jamu adalah produk warisan tradisional yang sebenarnya telah dikenal ratusan tahun lalu. Sebelum pengobatan modern dikenalkan dan menjadi maju seperti saat ini, jamu merupakan produk warisan dari nenek moyang dalam menjaga kesehatan. Perubahan peradaban dan kebudayaan mengakibatkan perubahan teknologi, produk, gaya hidup dan konsumsi, termasuk perkembangan dunia pengobatan dan farmasi. Harnack et al. (2004) menunjukkan perkembangan penjualan produk herbal yang meningkat secara dramatis di Amerika Serikat dalam beberapa tahun terakhir. World Health Organization (WHO) melalui resolusi tahun 1977 menyatakan bahwa pelayanan kesehatan masyarakat tidak dapat merata sampai tahun 2000 tanpa mengikutsertakan sistem pengobatan tradisional (Supardi dan Notosiswoyo 2005). Hal ini maknanya pengobatan tradisonal merupakan salah satu elemen dalam upaya pelayanan kesehatan.

Berdasarkan informasi dapat diketahui bahwa sebagian besar informan yang dipilih secara acak dari anggota masyarakat sebagian besar mengatakan pernah mengkonsumsi jamu dalam hidupnya. Alasan mengkonsumsi jamu di antaranya adalah cocok, minum jamu sebagai bagian dari budaya. Hal ini sejalan dengan pernyataan di atas di mana produk jamu adalah produk warisan tradisional yang sebenarnya telah dikenal ratusan tahun lalu. Maknanya jamu merupakan bagian dari budaya dan individu yang mengkonsumsi jamu merupakan pilihan pribadi. Bentuk jamu di antaranya adalah tablet, bubuk dan cair. Beberapa jamu bubuk/puyer agar tidak terasa pahit bahkan ada yang dikemas secara kapsul. Hal ini dapat diinterpretasi bahwa jamu dewasa ini juga menyesuaikan dengan perkembangan permintaan pasar masyarakat berkaitan dengan kemasan. Hal ini akan meningkatkan konsumsi jamu masyarakat karena kemasan jamu menyerupai obat modern. Merek jamu yang pernah di konsumsi diperoleh infomasi di antaranya adalah Sidomuncul, Tolak Angin, Kunyit Asem, Kuku Bima. Merek lain sehat wanita Nyonya Menir. Buyung upi Jamu Jago, Basmurat dan Pegel Linu Jap Djago. Antangin, Jamu Orang Tua, Air Mancur, Borobudur.

\section{Faktor pemasaran produk jamu}

Pemasaran suatu produk jamu banyak dipengaruhi karena iklan dan ketersediaan di tengah-tengah masyarakat (toko-warung-penjual keliling). Sikap dihasilkan oleh evaluasi atau pembelajaran atau pengetahuan konsumen terhadap obyek. Pengetahuan akan produk diperoleh dari pembelajaran kognitif (Mowen dan Minor 2001) yang dilakukan oleh konsumen. Maksud dari pembelajaran kognitif adalah berkaitan dengan pengetahuan konsumen. Konsumen dalam penelitian ini adalah konsumen jamu. Pengulangan iklan berperan dalam peningkatan pengetahuan konsumen akan produk (Indriyanti dan Ihalauw 2002). Pembelajaran adalah proses bagaimana individu konsumen mendapatkan pengetahuan konsumsi dan pembelian serta pengalaman yang akan diaplikasikan pada pembelian yang akan datang. Pada konteks ini konsumen memiliki ingatan untuk membeli suatu produk.

Menggunakan teori pemasaran iklan adalah bagian dari pembelajaran pada konsumen pada suatu produk. Pembelajaran pada konsumen merupakan proses yang terjadi terus menerus. Hasil pembelajaran adalah pengetahuan dan pengalaman (Schiffman dan Kanuk 2000). Pembelajaran dapat dibagi menjadi dua yaitu behavioral learning dan cognitive learning. Behavioral learning merupakan pembelajaran prilaku dari konsumen dan cognitive learning merupakan pengetahuan akan produk tertentu. Perbedaan tersebut didasarkan pada elemen perubahan yang terjadi pada konsumen. Dengan 
demikian dapat disimpulkan bahwa konsumen memiliki perbedaan tingkat pengetahuan tentang produk dan perbedaan tipe pengetahuan tentang produk (Peter dan Olson 2002).

Berdasarkan informasi, hampir keseluruhan informan menyatakan iklan efektif untuk pemasaran produk jamu. Pemasaran melalui iklan efektif untuk mengenalkan produk pada konsumen. Hal ini sejalan dengan pendapat Mowen dan Minor di mana "pengetahuan akan produk diperoleh dari pembelajaran kognitif" (Mowen dan Minor 2001). Pengetahuan tentang produk jamu dikenal masyarakat selain dari iklan diperoleh dari orang-orang terdekat baik keluarga, atau anggota masyarakat. Hal ini karena interaksi sosial merupakan upaya membangun opini dan merupakan pemasaran yang efektif. Berdasarkan informasi diketahui bahwa konsumen membeli atau memperoleh jamu pada tempat toko, minimarket, jualan keliling. Interpretasinya adalah untuk memperoleh jamu sangatlah mudah. Jamu yang impor dari luar negeri membuka toko eksklusif pada tempat-tempat tertentu, sebaliknya jamu tradisional banyak dijual oleh penjual keliling.

\section{Faktor sosial mengkonsumsi jamu}

Faktor sosial (keluarga dan orang sekitar) dapat mempengaruhi individu dalam mengkonsumsi jamu. Hal ini bagian lain dari penyebarluasan jamu pada masyarakat. Jamu merupakan bagian dari budaya. Sebagai sebuah budaya jamu dikenalkan selain dari iklan juga dikenalkan dan disosialisasikan dan disarankan dari keluarga dan orang-orang terdekat. Sebagian besar informan memberikan informasi bahwa mengenal, membeli jamu sebagian besar berpendapat mendapatkan pengetahuan jamu dari orang tua, dan sebagian dari tetangga. Berdasarkan informasi tersebut faktor sosial konsumen juga dipengaruhi dalam keputusan seorang individu mengkonsumsi jamu.

\section{Faktor budaya mengkonsumsi jamu}

Mengkonsumsi jamu merupakan suatu budaya. Budaya yang berkembang dan berubah mempengaruhi juga perilaku konsumsi konsumen jamu. Perubahan tersebut berakibat terjadinya perubahan pada faktor psikologis konsumen misalnya persepsi, sikap terhadap jamu, motivasi minum jamu, pengetahuan dan kepercayaan tentang jamu dan gaya hidup yang terkait dengan hidup sehat dari bahan alami. Hal ini tidak dapat terelakkan karena pada dasarnya manusia memang selalu berkembang dan tidak ada yang dapat dipastikan dari perilaku manusia sebagai konsumen. Selain itu budaya minum jamu yang tidak diturunkan ke generasi berikutnya akan lebih memperparah perubahan tersebut. Berdasarkan informasi dapat diketahui bahwa minum jamu sudah dibudayakan sejak dini pada beberapa keluarga khususnya pada daerah Mataraman dan Madura. Budaya mengkonsumsi jamu merupakan bagian dari kebutuhan, utamanya kalau individu tersebut sakit. Anggota keluarga adalah pihak utama yang membudayakan mengkonsumsi jamu. Pada saat peneliti menanyakan lebih dulu mana yang dilakukan pada saat sakit/kurang enak badan ke dokter atau beli jamu/ke toko jamu, diperoleh informasi sebagian besar informan menjawab ke dokter. Hal ini tidak dapat dipungkiri realitasnya individu mengkonsumsi jamu untuk mendampingi obat farmasi. Maknanya dokter masih dominan dalam pelayanan kesehatan pada masyarakat. Secara teori persepsi, sikap terhadap jamu, motivasi minum jamu, pengetahuan dan kepercayaan tentang jamu dan gaya hidup yang terkait dengan hidup sehat dari bahan alami juga menjadi variabel utama orang memilih mengkonsumsi jamu.

\section{Faktor psikologi mengkonsumsi jamu}

Minum jamu adalah salah satu tradisi khas masyarakat Indonesia. Kegiatan mengkonsumsi jamu selain dipengaruhi oleh pembelajaran budaya, juga sangat dipengaruhi oleh faktor lain. Faktor-faktor tersebut antara lain adalah keluarga, kelompok referensi dan faktor psikologis misalnya sikap terhadap produk tersebut (Schiffman dan Kanuk 2000). Sikap adalah faktor psikologis yang paling dekat dengan keputusan konsumsi karena di dalam unsur sikap terdapat kecenderungan untuk berperilaku mendekat atau menjauh dari produk. Sikap positif akan mengarahkan niat konsumen pada produk dan sebaliknya sikap negatif akan mengurungkan niat konsumen. Sikap antara lain dibentuk melalui 
evaluasi terhadap atribut-atribut produk serta kepercayaan akan produk atau merek (Simamora 2002). Produk dengan atribut yang tidak disukai akan menghasilkan sikap negatif. Sebagian besar mengatakan cocok menggunakan jamu dan jamu lebih cos pleng (lebih cepat menyembuhkan). Hal ini dapat diinterpertasi bahwa sikap positif individu akan mengarahkan niat konsumen pada produk jamu/ mengkonsumsi jamu. Sikap posistif itu tercermin pada pendapat-pendapat seperti dipaparkan di atas bahwa individu informan cocok mengkonsumsi jamu dan secara psikologi dianggap lebih mampu menyembuhkan penyakit. Hal ini adalah variabel psikologis seseorang yang muncul karena stimulus konsumsi jamu.

Pada saat peneliti menanyakan pada informan lebih puas mengkonsumsi jamu atau obat dalam menjaga tubuh atau menyembuhkan penyakit, ada sikap positif informan pada jamu. Namun pada konteks permasalahan kesehatan tertentu sebagian informan masih percaya pada obat farmasi baru kedudukan jamu disandingkan dengan obat. Pada pendapat lain informan mengatakan permasalahan bukan puas atau tidak puas namun di antara jamu dan obat mana yang lebih cepat menyembuhkan itu yang utama. Mencari jalan kesembuhan dari suatu sakit ditempuh dengan model pengobatan baik secara obat farmasi maupun konsumsi jamu. Generalisasi dari aspek psikologi adalah informan memiliki sikap positif pada jamu karena ada kecocokan dan lebih menyembuhkan namun demikian sebagian informan pada kasus tertentu lebih percaya pada pengobatan farmasi. Titik temu dari kontradiksi pendapat diatas adalah kesembuhan menjadi variabel utama yang dituju, apakah dengan jalan konsumsi jamu atau obat itu adalah aspek proses.

\section{Faktor harga mengkonsumsi jamu}

Konsumen menyukai produk jamu yang diberi label pada pembungkusnya yang dapat memberikan informasi pada konsumen. Label tersebut misalnya adalah label harga, komposisi bahan, petunjuk pemakaian, manfaat dan sebagainya. Hal ini bagi konsumen aspek harga, komposisi bahan, petunjuk pemakaian, dan manfaat merupakan bagian penting untuk memberikan informasi pada konsumen. Selain itu konsumen juga menyukai jamu yang mudah dikonsumsi dan dikemas secara praktis. Menurut pendapat Mowen dan Minor adalah keinginan untuk berperilaku dalam pembelian ditentukan oleh sikap terhadap perilaku yang dilakukan dan norma subyektif yang dianut konsumen (Mowen dan Minor 2001).

Niat berperilaku merupakan prediktor terbaik dari perilaku aktual dan merupakan proposisi seseorang konsumen dengan tindakan yang akan datang atau rencana untuk melibatkan perilaku untuk mencapai tujuan (Peter dan Olson 2002). Niat berperilaku dalam pembelian dapat diukur dengan tingkat kemungkinan yang dimiliki konsumen bahwa mereka akan membentuk perilaku pembelian. Peneliti menanyakan pada konsumen masyarakat bahwa dilihat dari segi harga lebih murah mana antara jamu dan obat. Harga menjadi faktor yang berpengaruh pada individu kaitannya dengan konsumsi jamu. Sebagian besar informan mengatakan bahwa harga jual jamu relatif terjangkau. Harga perlu dicantumkan pada label. Selain label harga perlu dicantumkan komposisi bahan, petunjuk pemakaian, manfaat jamu. Pada beberapa orang masalah harga tidak menjadi persoalan dengan catatan bahwa khasiat jamu baik untuk tubuh. Bahkan untuk jamu import yang harganya mahal dari China dan Korea bagi beberapa informan juga tidak menjadi persoalan.

\section{Faktor legalitas lembaga kesehatan dalam peredaran dan penggunaan jamu di rumah sakit dan puskesmas}

Peningkatan konsumsi jamu oleh masyarakat selain ditentukan faktor di atas juga dipengaruhi oleh faktor legalitas jamu oleh lembaga kesehatan (rumah sakit dan puskesmas). Hal ini semenjak diberlakukannya Peraturan Menteri Kesehatan Republik Indonesia Nomor: 003/MENKES/PER/I/2010 Tentang Saintifikasi Jamu dalam Penelitian Berbasis Pelayanan Kesehatan. Tujuan pengaturan saintifikasi jamu adalah: a. Memberikan landasan ilmiah (evidence based) penggunaan jamu secara empiris melalui penelitian berbasis pelayanan kesehatan. $b$. Mendorong terbentuknya jejaring dokter atau dokter gigi dan tenaga kesehatan lainnya sebagai 
peneliti dalam rangka upaya preventif, promotif, rehabilitatif dan paliatif melalui penggunaan jamu. c. Meningkatkan kegiatan penelitian kualitatif terhadap pasien dengan penggunaan jamu. $d$. Meningkatkan penyediaan jamu yang aman, memiliki khasiat nyata yang teruji secara ilmiah, dan dimanfaatkan secara luas baik untuk pengobatan sendiri maupun dalam fasilitas pelayanan kesehatan (Pasal: 2 Permenkes, Nomor: 003/MENKES/PER/I/2010). Pada saat peneliti menanyakan pada informan apakah pernah berobat ke puskesmas atau rumah sakit dan diberikan jamu, diperoleh informasi belum pernah mendapat pelayanan jamu dari lembaga kesehatan puskesmas atau rumah sakit. Namun demikian beberapa informan mengetahui kalau pada pelayanan puskesmas atau rumah sakit ada poli khusus pengobatan tradisional atau sering disebut poli batra. RS Dr. Soetomo Surabaya punya poli Obat Tradisional Surabaya (OTI), begitu juga beberapa puskesmas di Surabaya seperti pada bagian sebelumnya sudah dipaparkan kalau memiliki poli batra (pengobatan tradisional). Berdasarkan informasi yang berasal dari informan di atas dapat diketahui bahwa sebagian masyarakat berpendapat bahwa untuk peredaran jamu pada masyarakat terdapat pengaturan. Sebagian lagi berpendapat bahwa peredaran obat di masyarakat tidak ada pengaturan atau lemah pengaturannya. Berdasarkan kondisi ini perlu pengawasan dan pengaturan peredaran obat agar tidak merugikan masyarakat.

\section{Peran strategis dinas kesehatan dalam kebijakan jamu pada pemerintah lokal}

Pemerintah lokal (pemerintah kabupaten/kota) selaku pihak yang paling dekat dengan masyarakat memiliki peran strategis dalam kebijakan kesehatan. Bidang kesehatan merupakan bidang yang didesentralisasi dengan menggunakan landasan hukum UU No.32 Th. 2004 tentang otonomi daerah. Pada era otonomi daerah dengan pengelolaan kewenangan pemerintah lokal dapat membuat inovasi kebijakan dalam integrasi penggunaan jamu (obat tradisional) untuk diterapkan pada pusat kesehatan masyarakat (puskesmas) atau rumah sakit umum daerah (RSUD).

Berdasarkan hasil penelitian yang dilakukan peneliti, Dinas Kesehatan Provinsi Jawa Timur hakikatnya telah mengakomodasi kebijakan pengobatan tradisional termasuk penggunaan jamu dalam pelayanan kesehatan masyarakat. Pemerintahan lokal pada tingkat Kota Surabaya memiliki inovasi kebijakan pelayanan kesehatan yang diterapkan (diimplementasi) dinas kesehatan melalui UPTD Puskesmas dinas Kesehatan dengan menerapkan poli pengobatan tradisional (batra) pada 7 puskesmas. Pelayanan puskesmas yang telah memiliki poli batra di antaranya adalah puskesmas Banyu Urip Surabaya, puskesmas Gundih Surabaya, puskesmas Jemursari Surabaya, puskesmas Manukan Kulon Surabaya, puskesmas Medokan Ayu Surabaya, puskesmas Pengirikan Surabaya, puskesmas Peneleh Surabaya. Pelayanan kesehatan pada Kabupaten Magetan dan Kabupaten Bangkalan belum menerapkan pelayanan pengobatan tradisonal pada Rumah Sakit Umum Daerah (RSUD) atau Puskesmas.

\section{Model pengelolaan jamu untuk meningkatkan kualitas kesehatan masyarakat}

Model pengelolaan jamu untuk meningkatkkan kualitas kesehatan masyarakat hakikatnya berangkat dari filosofi yaitu pelayanan kesehatan bagi semua orang dengan harga yang terjangkau. Hal ini sejalan dengan Undang-Undang Dasar 1945 pasal 28 H ayat (1) yang menyatakan bahwa "setiap orang berhak untuk hidup sejahtera lahir dan batin, bertempat tinggal dan mendapatkan lingkungan hidup yang baik dan sehat serta berhak memperoleh pelayanan kesehatan”. Dalam Undang-Undang Dasar 1945 pasal 34 ayat 3 disebutkan "Negara bertanggung jawab atas penyediaan fasilitas pelayanan kesehatan dan fasilitas pelayanan umum yang layak. Lebih lanjut Undang Undang Nomor 23 Tahun 1992 tentang Kesehatan pasal 4 menyatakan bahwa setiap orang mempunyai hak yang sama dalam memperoleh derajat kesehatan yang optimal. Berdasarkan perundang-undangan di atas peneliti merumuskan model pengelolaan jamu untuk meningkatkan kualitas kesehatan masyarakat didasarkan beberapa hal (a) peningkatan pelayanan kesehatan melalui poli pengobatan tradisional (batra) termasuk penggunaan jamu, (b) meningkatkan derajat kesehatan secara optimal dengan jamu. 
Model pengelolaan jamu untuk peningkatan pelayanan kesehatan dilakukan dengan upaya peningkatan mutu produk, menguatkan sektor pendukung, meningkatkan sosialisasi bagi masyarakat non konsumen, dan pembentukan kebiasaan bagi masyarakat konsumen. Tahapan ini merupakan langkah-langkah strategis yang berimplikasi pada pelaksanaan kebijakan pengembangan obat tradisional Indonesia. Langkah-langkah pengembangan jamu Indonesia bisa dilakukan dengan jalan sebagai berikut: 1) Pendampingan di daerah (produsen) sentra produksi jamu berupa peningkatan kualitas (training kualitas). Langkah ini dilakukan dengan pendampingan intensif pengelolaan jamu secara modern yang lebih baik. 2) Riset dan pengembangan produk jamu Indonesia. Agar jamu dapat diterima baik perlu didukung dengan penelitian secara ilmiah. 3) Mengurangi pajak jamu. Langkah untuk memperbanyak industri jamu dilakukan dengan pengurangan pajak jamu. 4) Mengembangkan tanaman obat untuk produksi jamu. Hal utama pengembangan jamu adalah perlu dukungan pengembangan tanaman obat untuk produksi jamu. 5) Sosialisasi hasil riset jamu. Agar jamu diterima masyarakat secara luas, maka perlu dilakukan sosialisasi hasil riset jamu secara ilmiah. 6) Standarisasi jamu. Jamu yang pembuatannya secara sederhana perlu ditingkatkan dengan standarisasi jamu untuk dikonsumsi masyarakat. 7) Pengawasan ketat pada peredaran dan produksi jamu. Banyaknya peredaran jamu yang banyak di masyarakat maka perlu dilakukan pengawasan secara ketat agar tidak merugikan masyarakat.

- Pendampingan di daerah (produsen) sentra produksi jamu berupa peningkatan kualitas (training kualitas)

- Riset dan pengembangan produk jamu Indonesia

- Mengurangi pajak jamu

- Mengembangkan tanaman obat untuk produksi jamu

- Sosialisasi hasil riset jamu

- standarisasi jamu

- pengawasan ketat pada peredaran dan produksi jamu

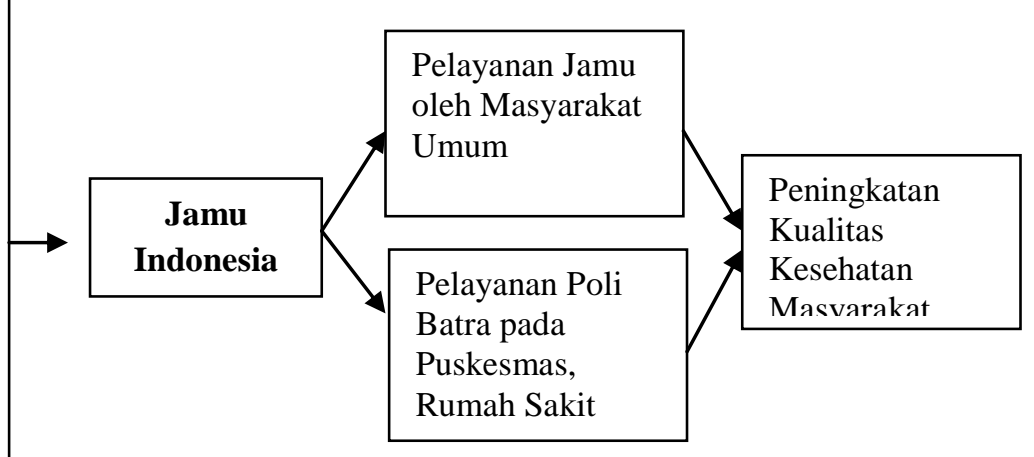

Gambar 1.

Model pengelolaan jamu

Sumber data: primer penelitian

\section{Simpulan}

Penerimaan penggunaan jamu sebagai alternatif penggunaan obat modern pada masyarakat ekonomi rendah-menengah dan atas secara umum tinggi (58\%). Hasil tersebut peneliti kategorikan tinggi karena di tengah berkembang pesat obat modern dan era globalisasi, sebagian besar masyarakat lebih dari 50\% masih mengkonsumsi/menggunakan jamu untuk menjaga kesehatan dan menyembuhkan penyakit. Konsumsi masyarakat terhadap jamu paling tinggi adalah ekonomi rendah (pendapatan kurang dari 1jt/bulan), sejumlah 58\% dari data responden. Masyarakat ekonomi menengah (pendapatan antara 1,5-5j//bulan) mengkonsumsi jamu 25\% dari responden. Masyarakat ekonomi atas (pendapatan $>5 \mathrm{jt} /$ bulan) cenderung pada pengobatan farmasi $(17 \%)$. Faktor yang menyebabkan tingginya penggunaan jamu sebagai alternatif penggunaan obat modern pada masyarakat ekonomi rendah-menengah dan atas adalah faktor pribadi, faktor pemasaran, faktor sosial, faktor budaya, faktor psikologi, faktor harga, dan faktor legalitas lembaga kesehatan (rumah sakit dan puskesmas). Pemerintah lokal melalui otonomi daerah memiliki peran strategis dalam pengelolaan jamu 
(pelayanan kesehatan) melalui inovasi kebijakan pelayanan kesehatan yang diterapkan pada pemerintah lokal. Dinas kesehatan pada pemerintah lokal sebatas mengimplementasi kebijakan yang telah dibuat pemerintah lokal. Sebagaimana pada pemerintah lokal Kota Surabaya terdapat poli batra pada 8 puskesmas, namun kabupaten Bangkalan dan Kabupaten Magetan belum menerapkan kebijakan pengobatan tradisional pada pelayanan kesehatan di RS dan Puskesmas. Model pengelolaan jamu untuk meningkatkan kualitas kesehatan masyarakat perlu ada pendampingan, riset, pengurangan pajak, pengembangan tanaman obat, sosialisasi hasil riset, standarisasi jamu, dan pengawasan yang ketat pada jamu di mana dapat digambarkan seperti di atas.

\section{Daftar Pustaka}

Badan Litbang Kesehatan (2010) Laporan hasil riset kesehatan dasar tahun 2010. Jakarta: Badan Litbang Kesehatan.

Bogdan R, Taylor S (1975) Introducing to qualitative methods: Phenomenological. New York: A Wiley Interscience Publication.

Hari Kebangkitan Jamu Indonesia (2008) 27 Mei 2008.

Harnack L, DeRosier K, Rydell S (2004) Survei of adults' attitudes and beliefs about herbal products. Journal of the American Pharmaceutical Association 43(5):596-601.

Indriyanti IS dan Ihalauw JJOI (2002) Pengulangan pesan suatu iklan dalam proses pembelajaran konsumen: Studi terhadap iklan pasta gigi Pepsodent. Jurnal Ekonomi dan Bisnis (Dian ekonomi) VIII (1):36-52.

Miles M, Huberman AM (1992) Analisis Data Kualitatif: Buku Sumber tentang Metode-metode Baru. Jakarta: UI Press.

Mowen JC and Minor M (2002) Perilaku Konsumen, Edisi 5 Jilid 2, alih bahasa: Dwi Kartini Yahya. Jakarta: Erlangga.

Mulyani (2007) Faktor-faktor yang memengaruhi konsumen membeli produk jamu. dalam http://eprints.upnjatim.ac.id/1710/1/file_1.pdf. [Diakses 20 April 2013]

Partini S (1999) Profil Sosial Budaya Lansia dalam Keluarga dan Komunitas di Provinsi Daerah Istimewa Yogyakarta, Laporan Penelitian, Yogyakarta, IKIP Yogyakarta.

Geertz H (1961) Keluarga Jawa. Jakarta: PT. Grafiti Press.

Pringgoutomo S (2007) Riwayat perkembangan pengobatan dengan tanaman obat di dunia timur dan barat. Buku Ajar Kursus Herbal Dasar untuk Dokter. Jakarta: Balai Penerbit FKUI; 1-5.

Tilaar M (2010) The Green Science of Jamu. Jakarta: PT Dian Rakyat.

Pols H (2010) The Triumph of Jamu. Dalam http://www.insideindonesia.org /stories/the-triumph-of jamu-26061327. [Diakses 6 September, 2012].

Pantja DS dan Darmawan D (2004) Pengaruh kesan kualitas layanan, harga, dan kepuasan mahasiswa PTS terhadap minat mereferensikan kampusnya. Journal Widya Manajemen dan Akuntansi Vol. 4 No 2, Agustus 190-204.

Peter PJ and Olson JC (2002) Consumer Behavior and Marketing strategy, 6 th edition, New York: McGraw Hill.

Purwaningsih EH (2013) Jamu, Obat Tradisional asli Indonesia: Pasang Surut Pemanfaatannya di Indonesia. Dalam http://journal.ui.ac.id/index.php /eJKI/article/viewFile/2065/1573. [Diakses 13 April 2014].

Pemerintah Republik Indonesia (2009) Undang-Undang No 36 tahun 2009 tentang Kesehatan

Pemerintah Republik Indonesia (2007) Kementerian Kesehatan Republik Indonesia. Riset Kesehatan Dasar.

Pemerintah Republik Indonesia (2010) Kementerian Kesehatan Republik Indonesia. Riset Kesehatan Dasar.

Supardi S dan Notosiswoyo M (2005) Pengobatan sendiri sakit kepala, demam, batuk, dan pilek pada masyarakat di Desa Ciwalen, Kecamatan Warungkondang, Kabupaten Cianjur, Jawa Barat. Majalah Ilmu Kefarmasian 2 (3) Agustus: 134-144.

Schiffman LG dan Kanuk LL (2000) Consumen Behavior, 7 th edition, Upper Saddle River. New Jersey: Prentice Hall. 
Simamora B (2002) Panduan riset perilaku konsumen. Jakarta: Gramedia

Webster A (2008) Herbal. Dalam www.indonesianembassy.ir/english/images/ Indonesian\%20Herbal. pdf. [Diakses 19 April, 2013]. 